\title{
DENTAL ENVIRONMENTAL STRESS DURING THE COVID-19 PANDEMIC AT THE JAGIELLONIAN UNIVERSITY MEDICAL COLLEGE, KRAKÓW, POLAND
}

\section{JOANNA ZARZECKA ${ }^{1}$, ELŻBIETA ZARZECKA-FRANCICA², ANDRZEJ GALA², KRZYSZTOF GĘBCZYŃSKI', and MALGORZATA PIHUT ${ }^{2}$}

Jagiellonian University Medical College, Kraków, Poland

Institute of Dentistry

${ }^{1}$ Department of Conservative Dentistry with Endodontics

${ }^{2}$ Department of Prosthodontics

\begin{abstract}
Objectives: The burden of stress experienced by dentistry students has been the subject of numerous studies aimed at defining the strongest stressors, and at reducing their intensity to improve the conditions and, consequently, the quality of education. Such studies have never been performed in the conditions of a pandemic caused by a new, unknown coronavirus. Therefore, the objective of the study was to identify the sources of their stress in the course of the studies, with reference to the COVID-19 pandemic. Material and Methods: A total of 334 dentistry students of the Institute of Dentistry at the Jagiellonian University Medical College were invited to take part in the study. They represented a range from the first to the fifth year of studies in the 2019/2020 academic year. The tool employed in the study was the Dental Environmental Stress (DES) questionnaire and 11 supplementary questions related to the pandemic. The study was carried out on June 1-25, 2020. Results: The participation rate was 72\%. Academic work presented the highest level of stress. A comparison of the overall levels of stress in particular domains as well as questions included in the DES survey revealed significant differences between students of individual years of studies in the 2019/2020 academic year. The strongest positive relationships between the supplementary questions and the DES domains appeared in the area of clinical factors. These concerned returning to clinical classes and contact with patients with regard to SARS-CoV-2 $\left(\mathrm{r}_{\mathrm{s}}=0.50, \mathrm{p}<0.001\right)$, contact with patients in connection with SARS-CoV-2 $\left(\mathrm{r}_{\mathrm{s}}=0.47, \mathrm{p}<0.001\right)$, and a lack of practical classes with patients in connection with the COVID-19 pandemic $\left(r_{s}=0.42, p<0.001\right)$. Conclusions: Dentistry students were subjected to stress resulting from a conflict between the perceived risk of returning to clinical classes and contact with patients due to SARS-CoV-2, and disruptions in the course of clinical education, which they perceived negatively. Int J Occup Med Environ Health. 2021;34(2):211-22
\end{abstract}

Key words:

environmental stress, dentistry students, COVID-19, pandemic, DES survey, hazards in the workplace

\section{INTRODUCTION}

In 2015, and several years later after 2018, WHO published a list of the top 8 communicable diseases threatening societies [1-3]. The diseases caused by the corona- viruses represented on that list, and the epidemics they evolved into, were SARS in 2002 and MERS in 2012. December 2019 marked the outbreak of SARS-CoV-2, which acquired the status of a pandemic on March 11, 2020. This

Funding: this research was supported by the Institute of Dentistry, Jagiellonian University Medical College (grant No. N41/DBS/000370). Received: October 30, 2020. Accepted: January 18, 2021.

Corresponding author: Elżbieta Zarzecka-Francica, Jagiellonian University Medical College, Institute of Dentistry, Department of Prosthodontics, Montelupich 4, 31-155 Kraków, Poland (e-mail: elzbieta.zarzecka@gmail.com). 
pandemic should not be treated as an isolated incident, since the history of epidemics in recent years has indicated that new viruses appear cyclically and the time elapsed between epidemics is growing shorter [4-9].

The human-to-human transmission of SARS-CoV-2 occurs by means of droplets, direct transmission via the nasal mucosa, the respiratory system, and the conjunctiva of the eye, or indirect transmission (contact transmission) through touching infected surfaces and then spreading the virus to the mouth, eyes, or nose. The transmission of the virus is possible via faeces, urine, saliva, and blood [4,10-12]. A SARS-CoV-2 carrier can infect 2.2-3.58 people, which implies that the number of people with this coronavirus doubles within a period of 7 days [11].

The environment of a dental surgery creates conditions conducive to the spread of the infection $[5,13]$. Work in the respiratory tract poses a direct infection threat. Additionally, during the operation of high-speed and ultrasonic dental tools, fine particles of dissected tissues, water, saliva, and/or blood are produced and suspended in the air. These particles, accumulating on surfaces, can constitute a source of an indirect contact infection. The coronavirus can survive on glass, metal, and plastic surfaces for as long as several days. At room temperature, the virus maintains its level of virulence from $2 \mathrm{~h}$ to 9 days, with increased activity in a moist environment.

In the case of medical services, the aspect of mental health is also significant. As shown in a study conducted in Poland on April 17-18, 2020, nearly half (48\%) of the professionally active Poles infected with SARS-CoV-2 and undergoing isolation at home were employees of the healthcare system [14]. Research among healthcare professionals during previous epidemics and the current pandemic indicated the presence of anxiety of varying intensity, depression of various degrees, and post-traumatic stress disorder. It was also found that stressors threatening life and health during an epidemic have a greater impact on young people and on those exposed to regular contact with the ill $[9,13,15-17]$.

In light of the presented facts and the incomplete knowledge of the new pathogen, education of dentistry students, and particularly clinical education, involves many challenges, since safety in the work of medical personnel, students, and patients must be maintained [6-8].

The burden of stress experienced by dentistry students has been the subject of numerous studies. This knowledge enables the identification and reduction of the intensity of the stressors in order to improve the conditions and, consequently, the quality of education. The tools used to identify stressors and their intensity were reliable and valid $[14,18]$. However, such studies have never been performed in the conditions of a pandemic caused by a new, unknown coronavirus. Additionally, the Dental Environmental Stress (DES) questionnaire has never been applied either to the dentistry students at the Jagiellonian University Medical College (JUMC) or to other dentistry students in Poland, so the results will be used to monitor the changes in stressors as the pandemic progresses.

Taking into account the special situation of dentistry students, it was decided to identify the sources of their stress in the course of studies, with reference to the COVID-19 pandemic.

\section{MATERIAL AND METHODS}

\section{Study design and participants}

A total of 334 dentistry students of the Institute of Dentistry at JUMC were invited to take part in the study. They represented a range from the first to the fifth year of studies in the 2019/2020 academic year. The study was voluntary and anonymous, consisting of the completion of the DES online survey and 11 supplementary questions related to the pandemic. The Google Forms program was used to carry out the study online on June 1-25, 2020. The representatives of the student government were asked to remind students to participate. 
The study was approved by the Bioethics Committee of the Jagiellonian University (No. 1072.6120.120.2020).

The DES survey was chosen because it is the tool most commonly used to measure the sources of stress among dentistry students in the available literature [19]. The modified version consists of 39 items grouped into 5 domains describing areas of stress specific to dental studies: living accommodation, personal factors, educational environment, academic work, and clinical factors [20,21]. The response to each item was scored on a 5-point scale: 0 - not pertinent, 1 - not stressful, 2 - slightly stressful, 3 - moderately stressful, and 4 - very stressful. Similarly, responses to the 11 questions related to the COVID-19 pandemic and attached to the DES survey were scored on a 5-point scale.

In order to identify the causes of stress among dental students in the course of studies, taking into account the COVID-19 pandemic, the following were compared: domains throughout the sample, the level of stress between the domains depending on the year of studies, and students in various years of studies in terms of the level of stress associated with particular questions in the DES questionnaire. The relationship between the levels of stress in individual domains and those associated with COVID-19 was examined as well.

The DES modified questionnaire was translated into Polish, for which the consent of its authors was obtained $[18,20]$. The translation was performed independently by 2 Polish-speaking dentists of the Institute of Dentistry at JUMC. Following the agreement on the final wording, bilingual (English/Polish) dental students of the School of Medicine in English (SME) at JUMC, in their fifth year of studies, were asked to provide a reverse translation.

\section{Statistical analysis}

Statistical analyses were performed with the use of IBM SPSS Statistics v. 26.0. and Jamovi v. 1.2.22. To analyze the reliability of the Polish-language DES survey, the following 2 coefficients were used: Cronbach's $\alpha$ and McDonald's $\omega$.

Descriptive statistics were calculated at first and in order to indicate which of the domains caused the highest level of stress in the studied sample, and analyses using the ANOVA method were performed in order to check the differences in the level of stress in individual DES domains depending on the year of studies.

In order to compare individual years of studies in terms of responses to the DES questionnaire and to questions related to COVID-19, an analysis was conducted using the Kruskal-Wallis test.

In order to establish relationships between quantitative and ordinal variables, a correlation analysis was performed using Spearman's rho coefficient. The level of significance was set at $\alpha=0.05$.

\section{RESULTS}

All domains of the Polish-language DES questionnaire were characterized by a satisfactory level of reliability $(\alpha>0.7)$; thus, the level of reliability of the entire questionnaire was considered high $(\alpha=0.923)$.

The study group consisted of 243 dentistry students at JUMC from a total 334 students. The participation rate was $72 \%$. The students of SME JUMC were excluded.

\section{Comparison of domains within the entire sample}

The analysis indicated no differences in the level of stress between the domains of living accommodation during studies and personal factors $(\mathrm{p}=0.656)$. The differences between the remaining domains were statistically significant. The highest level of stress concerned the domain of academic work, which was significantly higher than the levels of stress regarding clinical factors $(p<0.001)$, educational environment $(\mathrm{p}<0.001)$, personal factors ( $p<0.001)$, and living accommodation $(p<0.001)$. Educational environment induced a higher level of stress in 


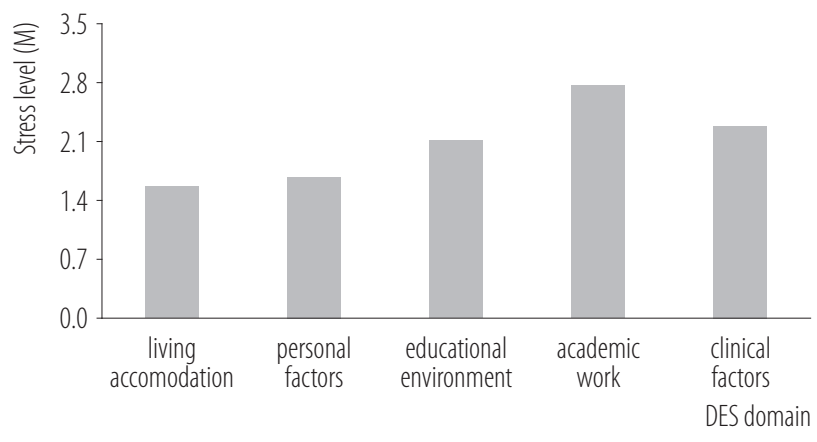

Figure 1. Stress levels in individual Dental Environmental Stress (DES) domains within the entire sample in the dentistry students $(\mathrm{N}=243$ ) of the Institute of Dentistry, the Jagiellonian University Medical College, June 1-25, 2020, Kraków, Poland

comparison to personal factors $(\mathrm{p}<0.001)$ and living accommodation $(\mathrm{p}<0.001)$.

The mean values of the stress levels in individual DES domains are presented in Figure 1.

\section{Comparison of domains by year of studies}

The obtained results showed no differences between the groups of students depending on the year of studies in terms of the level of stress related either to living ac- commodation during the period of studies or to personal factors. For the remaining domains - educational environment, academic work, and clinical factors - as well as for the overall DES score, differences between the groups were significant.

Higher levels of stress related to academic work were reported by students in their fifth year of studies compared to those in their second $(p<0.001)$, third $(p=0.001)$, or fourth $(p<0.001)$ years, but they did not differ from those of first-year students $(p=0.086)$. Differences in the levels of stress related to academic work between the remaining groups were statistically insignificant.

First-year students showed significantly lower levels of stress related to clinical factors compared to students in their third $(\mathrm{p}<0.001)$, fourth $(\mathrm{p}<0.001)$ or fifth $(p<0.001)$ years. Differences in the levels of stress between the third-, fourth-, and fifth-year students were statistically insignificant.

First-year students showed significantly lower overall levels of stress (the overall DES score) compared to those in their third $(p=0.035)$ or fifth $(p<0.001)$ years.

Table 1 summarizes the analyses.

Table 1. Results of a 1-way analysis of variance for differences in the levels of stress in particular domains depending on the year of studies in dentistry students of the Institute of Dentistry, the Jagiellonian University Medical College, June 1-25, 2020, Kraków, Poland

\begin{tabular}{|c|c|c|c|c|c|c|c|c|c|c|c|c|c|}
\hline \multirow{3}{*}{ Variable } & \multicolumn{10}{|c|}{$\begin{array}{c}\text { Participants } \\
(\mathrm{N}=243)\end{array}$} & \multirow{3}{*}{$\mathrm{F}$} & \multirow{3}{*}{$\mathrm{p}$} & \multirow{3}{*}{$\eta^{2}$} \\
\hline & \multicolumn{2}{|c|}{$\begin{array}{l}\text { first year } \\
(\mathrm{N}=31)\end{array}$} & \multicolumn{2}{|c|}{$\begin{array}{c}\text { second year } \\
(\mathrm{N}=40)\end{array}$} & \multicolumn{2}{|c|}{$\begin{array}{l}\text { third year } \\
(\mathrm{N}=69)\end{array}$} & \multicolumn{2}{|c|}{$\begin{array}{l}\text { fourth year } \\
(\mathrm{N}=37)\end{array}$} & \multicolumn{2}{|c|}{$\begin{array}{l}\text { fifth year } \\
(\mathrm{N}=66)\end{array}$} & & & \\
\hline & M & SD & M & $\mathrm{SD}$ & M & $\mathrm{SD}$ & $\mathrm{M}$ & $\mathrm{SD}$ & $\mathrm{M}$ & $\mathrm{SD}$ & & & \\
\hline Total DES result & 1.82 & 0.54 & 1.92 & 0.51 & 2.16 & 0.59 & 2.06 & 0.54 & 2.36 & 0.47 & 7.42 & $<0.001$ & 0.11 \\
\hline living accommodation & 1.38 & 0.92 & 1.63 & 1.02 & 1.55 & 0.91 & 1.67 & 0.98 & 1.59 & 0.90 & 0.48 & 0.748 & 0.01 \\
\hline personal factors & 1.59 & 0.45 & 1.55 & 0.51 & 1.69 & 0.57 & 1.63 & 0.52 & 1.81 & 0.57 & 1.78 & 0.132 & 0.03 \\
\hline educational environment & 1.97 & 0.74 & 1.85 & 0.62 & 2.11 & 0.84 & 1.98 & 0.73 & 2.41 & 0.77 & 4.35 & 0.002 & 0.07 \\
\hline academic work & 2.77 & 0.65 & 2.63 & 0.61 & 2.65 & 0.77 & 2.52 & 0.73 & 3.12 & 0.51 & 8.97 & 0.001 & 0.10 \\
\hline clinical factors & 1.27 & 1.03 & 1.89 & 0.94 & 2.60 & 0.78 & 2.41 & 0.73 & 2.62 & 0.66 & 15.01 & $<0.001$ & 0.26 \\
\hline
\end{tabular}

DES - Dental Environmental Stress questionnaire. 
Comparison of students of different years of studies

in terms of the level of stress

associated with particular questions

\section{in the DES questionnaire}

Statistically significant differences between the years of studies were noted in the questions presented below. These include items from all domains except living accommodation.

In the domain of personal factors, the level of stress in firstyear students, concerning the necessity to postpone marriage due to studies, was lower than for students in their fifth $(p=0.019)$ or third $(p<0.001)$ years. The differences between the remaining years of studies were insignificant. In the domain of educational environment, the level of stress induced by expectations vs. reality of attending a dental school was significantly higher among students in their fifth year of studies compared to those in their first $(p=0.031)$, second $(p=0.001)$ or third $(p=0.024)$ years. Similarly, as regards the approachability of staff (the availability of staff for students), the stress level was higher compared to second-year students $(\mathrm{p}=0.024)$.

The level of stress associated with the fear of failing a course or the entire year was lower among students in their third year than among those in their first $(p=0.017)$ or fifth $(p<0.001)$ years. Similar differences occurred in the fourth year of studies: those students experienced a lower level of anxiety than students in their first $(p=0.007)$ or fifth $(\mathrm{p}<0.001)$ years.

In the domain of clinical factors, the level of stress in firstyear students associated with transition from preclinical to clinical activities was significantly lower than in students of the remaining years of studies (second: $p=0.031$, third: $p=0.004$, fourth: $p=0.032$, fifth: $p=0.022$ ).

In fifth-year students, the level of stress related to transition from preclinical to clinical activities was higher than in first-year students $(\mathrm{p}=0.009)$.

In first-year students, stress resulting from completing clinical requirements was lower than in students in their third $(\mathrm{p}<0.001)$, fourth $(\mathrm{p}<0.001)$ or fifth $(\mathrm{p}<0.001)$ years, and lower for second-year students than for those in their third $(\mathrm{p}<0.001)$ or fifth $(\mathrm{p}=0.001)$ years.

Similarly, for first-year students, stress related to concerns about the treatment grades awarded was lower than for students in their third $(p<0.001)$, fourth $(p<0.001)$ or fifth $(\mathrm{p}=0.010)$ years, and lower for students in their second year than for those in their third $(p=0.001)$ or fifth $(\mathrm{p}=0.007)$ years.

Detailed results of the analysis are presented in Table 2.

\section{Relationship between the level of stress \\ in individual domains and the stress level associated with the COVID-19 pandemic}

The higher the level of stress related to living accommodation during studies, the higher the level of stress associated with returning home and studying at home in connection with the COVID-19 pandemic. Similarly, the higher the level of stress related to living accommodation during studies, the higher the level of stress related to an increased number of extracurricular obligations, to the fear of back$\log$ in connection with the pandemic, and to changes in the form of contact with assistants during the pandemic. These correlations were positive and weak.

The strongest positive relationships between the supplementary questions concerning the pandemic and the DES domains appeared in the area of clinical factors. These concerned a return to clinical classes and contact with patients with regard to SARS-CoV-2 $\left(\mathrm{r}_{\mathrm{s}}=0.50, \mathrm{p}<0.001\right)$, contact with patients in connection with SARS-CoV-2 $\left(\mathrm{r}_{\mathrm{s}}=0.47, \mathrm{p}<0.001\right)$, and a lack of practical classes with patients in connection with the COVID-19 pandemic $\left(\mathrm{r}_{\mathrm{s}}=0.42, \mathrm{p}<0.001\right)$.

The strongest correlation associated with school-related stress was observed in connection with the fear of back$\log$ arising from the COVID-19 pandemic $\left(r_{s}=0.44\right.$, $\mathrm{p}<0.001)$.

Detailed results of the analyses are presented in Table 3. 
Table 2. Comparison of dentistry students of the Institute of Dentistry, the Jagiellonian University Medical College, in different years of studies in terms of the levels of stress associated with particular questions in the Dental Environmental Stress (DES) questionnaire, June 1-25, 2020, Kraków, Poland

\begin{tabular}{|c|c|c|c|c|c|c|c|c|c|}
\hline \multirow{2}{*}{ DES domain } & \multicolumn{6}{|c|}{$\begin{array}{c}\text { Participants } \\
(\mathrm{Me}(\mathrm{IQR})) \\
(\mathrm{N}=243)\end{array}$} & \multirow{2}{*}{$\mathrm{H}(4)$} & \multirow{2}{*}{$\mathrm{p}$} & \multirow{2}{*}{$1^{2}$} \\
\hline & total & $\begin{array}{l}\text { first year } \\
(\mathrm{N}=31)\end{array}$ & $\begin{array}{l}\text { second year } \\
(\mathrm{N}=40)\end{array}$ & $\begin{array}{l}\text { third year } \\
(\mathrm{N}=69)\end{array}$ & $\begin{array}{c}\text { fourth } \\
\text { year } \\
(\mathrm{N}=37)\end{array}$ & $\begin{array}{l}\text { fifth year } \\
(\mathrm{N}=66)\end{array}$ & & & \\
\hline \multicolumn{10}{|l|}{ Living accommodation } \\
\hline moving away from home & $1(2)$ & $1(2)$ & $1(2.75)$ & $1(1)$ & $1(2.5)$ & $1(1.25)$ & 2.78 & 0.595 & 0.01 \\
\hline study environment & $2(2)$ & $2(2)$ & $2(1.75)$ & $2(2)$ & $2(2)$ & $2(2)$ & 1.63 & 0.804 & 0.01 \\
\hline lack of home atmosphere & $1(2)$ & $1(2)$ & $1(2)$ & $1(1.5)$ & $1(2)$ & $1(2)$ & 3.23 & 0.520 & 0.01 \\
\hline \multicolumn{10}{|l|}{ Personal factors } \\
\hline making friends & $2(1)$ & $2(1)$ & $2(1)$ & $2(1)$ & $2(2)$ & $2(1)$ & 6.40 & 0.171 & 0.03 \\
\hline financial responsibilities & $2(2)$ & $2(2)$ & $2(3)$ & $2(1)$ & $2(2)$ & $2(1.5)$ & 3.55 & 0.470 & 0.02 \\
\hline personal physical health & $2(2)$ & $2(2)$ & $2(2)$ & $2(2)$ & $2(1.5)$ & $2(2)$ & 4.00 & 0.406 & 0.02 \\
\hline intimate relationships & $2(2)$ & $2(2)$ & $2(1)$ & $1(1.5)$ & $1(1)$ & $2(2)$ & 3.48 & 0.481 & 0.01 \\
\hline need to postpone marriage & $1(1)$ & $0(0)$ & $0.5(1)$ & $1(2)$ & $1(1.5)$ & $1(1)$ & 17.30 & 0.002 & 0.07 \\
\hline need to postpone having children & $1(2)$ & $0(1)$ & $1(1)$ & $1(2)$ & $1(2)$ & $1(2)$ & 1.55 & 0.001 & 0.08 \\
\hline playing multiple roles & $2(2)$ & $2(2)$ & $2(2)$ & $2(1.5)$ & $2(2)$ & $3(1.25)$ & 8.42 & 0.077 & 0.04 \\
\hline $\begin{array}{l}\text { conflict with a spouse/mate } \\
\text { over career development }\end{array}$ & $1(2)$ & $0(2)$ & $1(1)$ & $1(1)$ & $1(1.5)$ & $2(2)$ & 22.78 & $<0.001$ & 0.10 \\
\hline lack of time for relaxation & $3(2)$ & $3(2)$ & $3(2)$ & $3(2)$ & $4(2)$ & $4(1)$ & 12.84 & 0.012 & 0.05 \\
\hline having children in the home & $0(0)$ & $0(0)$ & $0(0.75)$ & $0(0)$ & $0(0)$ & $0(0)$ & 1.58 & 0.812 & 0.01 \\
\hline $\begin{array}{l}\text { having reduced holidays compared } \\
\text { with other students }\end{array}$ & $2(2)$ & $2(1)$ & $2(2)$ & $2(2)$ & $2(2)$ & $2(2)$ & 4.05 & 0.400 & 0.02 \\
\hline $\begin{array}{l}\text { fear of going out due to crime } \\
\text { (COVID-19) }\end{array}$ & $2(2)$ & $2(1)$ & $2(2)$ & $2(2)$ & $2(1.5)$ & $2(2)$ & 3.90 & 0.419 & 0.02 \\
\hline $\begin{array}{l}\text { dependency (for example drugs, } \\
\text { alcohol) }\end{array}$ & $0(1)$ & $0(1)$ & $0(1)$ & $0(1)$ & $0(1)$ & $0(1)$ & 0.67 & 0.955 & 0.00 \\
\hline \multicolumn{10}{|l|}{ Educational environment } \\
\hline $\begin{array}{l}\text { expectations vs. reality of attending } \\
\text { a dental school }\end{array}$ & $3(1)$ & $2(2)$ & $2(2)$ & $3(1)$ & $2(1)$ & $3(2)$ & 20.52 & $<0.001$ & 0.09 \\
\hline availability of academic teachers & $2(2)$ & $2(2)$ & $1(1)$ & $2(2)$ & $1(1)$ & $2(2)$ & 11.23 & 0.024 & 0.05 \\
\hline approachability of staff & $2(2)$ & $1(2)$ & $2(1)$ & $2(2)$ & $1(1)$ & $2(2)$ & 5.52 & 0.238 & 0.02 \\
\hline $\begin{array}{l}\text { criticism of academic or clinical } \\
\text { work }\end{array}$ & $3(2)$ & $3(2)$ & $2(2.75)$ & $3(2)$ & $3(1.5)$ & $3(2)$ & 8.61 & 0.072 & 0.04 \\
\hline $\begin{array}{l}\text { rules and regulations of the dental } \\
\text { school }\end{array}$ & $3(1)$ & $2(2)$ & $2(1)$ & $2(2)$ & $2(1)$ & $3(2)$ & 9.12 & 0.058 & 0.04 \\
\hline $\begin{array}{l}\text { discrimination due to race, } \\
\text { nationality, gender, or social class }\end{array}$ & $1(1)$ & $1(1)$ & $1(1.75)$ & $1(2)$ & $1(2)$ & $1(2)$ & 4.72 & 0.317 & 0.02 \\
\hline \multicolumn{10}{|l|}{ Academic work } \\
\hline amount of assigned course work & $3(2)$ & $3(2)$ & $3(2)$ & $3(2)$ & $3(2)$ & $4(1)$ & 15.32 & 0.004 & 0.07 \\
\hline
\end{tabular}


Table 2. Comparison of dentistry students of the Institute of Dentistry, the Jagiellonian University Medical College, in different years of studies in terms of the levels of stress associated with particular questions in the Dental Environmental Stress (DES) questionnaire, June 1-25, 2020, Kraków, Poland - cont.

\begin{tabular}{|c|c|c|c|c|c|c|c|c|c|}
\hline \multirow{2}{*}{ DES domain } & \multicolumn{6}{|c|}{$\begin{array}{c}\text { Participants } \\
(\mathrm{Me}(\mathrm{IQR})) \\
(\mathrm{N}=243)\end{array}$} & \multirow{2}{*}{$\mathrm{H}(4)$} & \multirow{2}{*}{$\mathrm{p}$} & \multirow{2}{*}{$\eta^{2}$} \\
\hline & total & $\begin{array}{l}\text { first year } \\
(\mathrm{N}=31)\end{array}$ & $\begin{array}{l}\text { second year } \\
(\mathrm{N}=40)\end{array}$ & $\begin{array}{l}\text { third year } \\
(\mathrm{N}=69)\end{array}$ & $\begin{array}{c}\text { fourth } \\
\text { year } \\
(\mathrm{N}=37)\end{array}$ & $\begin{array}{l}\text { fifth year } \\
(\mathrm{N}=66)\end{array}$ & & & \\
\hline \multicolumn{10}{|l|}{ Academic work - cont. } \\
\hline difficulty of course work & $3(2)$ & $3(2)$ & $3(1)$ & $3(1.5)$ & $3(1)$ & $3(1)$ & 6.84 & 0.144 & 0.03 \\
\hline $\begin{array}{l}\text { fear of backlog (not being able } \\
\text { to catch up if falling behind) }\end{array}$ & $4(1)$ & $4(1)$ & $3.5(2)$ & $3(2)$ & $3(2)$ & $4(1)$ & 8.85 & 0.065 & 0.04 \\
\hline competition for grades & $2(2)$ & $1(1)$ & $2(1.75)$ & $1(2)$ & $1(1)$ & $2(2)$ & 18.92 & 0.001 & 0.08 \\
\hline $\begin{array}{l}\text { fear of failing course } \\
\text { or the entire year }\end{array}$ & $4(1)$ & $4(0)$ & $4(1)$ & $3(2)$ & $3(2)$ & $4(0)$ & 30.15 & $<0.001$ & 0.13 \\
\hline $\begin{array}{l}\text { uncertainty as to whether the choice } \\
\text { of dental studies was the right one }\end{array}$ & $2(2)$ & $2(3)$ & $1(1)$ & $2(1)$ & $2(1)$ & $2(3)$ & 15.63 & 0.004 & 0.07 \\
\hline uncertainty about dental career & $2(2)$ & $2(2)$ & $2(0.75)$ & $2(1.5)$ & $2(1)$ & $3(2)$ & 22.53 & $<0.001$ & 0.10 \\
\hline examinations & $4(1)$ & $4(0)$ & $4(0.75)$ & $4(1)$ & $3(1)$ & $4(0)$ & 21.63 & $<0.001$ & 0.09 \\
\hline $\begin{array}{l}\text { lack of input in the decision-making } \\
\text { process in the dental school }\end{array}$ & $2(3)$ & $2(3)$ & $2(2)$ & $3(2.5)$ & $1(1)$ & $3(2)$ & 21.86 & $<0.001$ & 0.09 \\
\hline \multicolumn{10}{|l|}{ Clinical factor } \\
\hline concerns about manual dexterity & $2(2)$ & $2(2)$ & $2(1)$ & $2(2)$ & $2(2)$ & $2(1.25)$ & 4.17 & 0.384 & 0.02 \\
\hline $\begin{array}{l}\text { transition from pre-clinical } \\
\text { to clinical activities }\end{array}$ & $3(2)$ & $1(3)$ & $3(3)$ & $2(2)$ & $3(1)$ & $3(1)$ & 14.29 & 0.006 & 0.06 \\
\hline $\begin{array}{l}\text { acquisition of manual skills } \\
\text { demanding precision }\end{array}$ & $2(2)$ & $1(2)$ & $2(2)$ & $2(2)$ & $2(2)$ & $2(1)$ & 11.30 & 0.023 & 0.05 \\
\hline completing clinical requirements & $2(2)$ & $0(1)$ & $1.5(3)$ & $3(2)$ & $2(1)$ & $3(1)$ & 59.20 & $<0.001$ & 0.25 \\
\hline $\begin{array}{l}\text { concern about treatment grades } \\
\text { awarded }\end{array}$ & $2(2)$ & $0(2)$ & $1(3)$ & $2(1.5)$ & $2(2)$ & $2(2)$ & 42.50 & $<0.001$ & 0.18 \\
\hline $\begin{array}{l}\text { difference in opinions with clinical } \\
\text { staff concerning treatment }\end{array}$ & $3(2)$ & $1(3)$ & $2(2)$ & $3(2)$ & $2(1)$ & $3(2)$ & 43.80 & $<0.001$ & 0.19 \\
\hline shortage of allocated clinical time & $3(2)$ & $0(1)$ & $2(3)$ & $4(1)$ & $3(1.5)$ & $3(2)$ & 72.64 & $<0.001$ & 0.31 \\
\hline patient management & $2(2)$ & $0(2)$ & $2(3)$ & $2(2)$ & $2(2)$ & $2(1)$ & 23.71 & $<0.001$ & 0.10 \\
\hline $\begin{array}{l}\text { confidence in one's own clinical } \\
\text { decision-making }\end{array}$ & $3(2)$ & $0(4)$ & $2(3.75)$ & $3(2)$ & $3(2)$ & $3(2)$ & 25.75 & $<0.001$ & 0.11 \\
\hline
\end{tabular}

\section{DISCUSSION}

Stress is "a particular relationship between the person and the environment that is appraised by the person as taxing or exceeding his or her resources and endangering his or her well-being." When appropriately intense, it motivates people towards many achievements; however, when the stimulation is excessive, it has a detrimental effect [18,22].

Impairment of intellectual function and learning ability under the influence of stress is of key significance in the context of studies. Under stress, students may show 
Table 3. Spearman's correlations for the relationship between the level of stress in individual domains and the level of stress associated with COVID-19 in dentistry students of the Institute of Dentistry, the Jagiellonian University Medical College, June 1-25, 2020, Kraków, Poland

\begin{tabular}{|c|c|c|c|c|c|c|c|c|c|c|}
\hline \multirow{3}{*}{$\begin{array}{l}\text { Stress factor associated } \\
\text { with COVID-19 }\end{array}$} & \multicolumn{10}{|c|}{ Spearman's correlation } \\
\hline & \multicolumn{2}{|c|}{$\begin{array}{c}\text { living } \\
\text { accommodation }\end{array}$} & \multicolumn{2}{|c|}{ personal factors } & \multicolumn{2}{|c|}{$\begin{array}{l}\text { educational } \\
\text { environment }\end{array}$} & \multicolumn{2}{|c|}{ academic work } & \multicolumn{2}{|c|}{ clinical factors } \\
\hline & $\mathrm{r}_{\mathrm{s}}$ & $\mathrm{p}$ & $\mathrm{r}_{\mathrm{s}}$ & $\mathrm{p}$ & $r_{s}$ & $\mathrm{p}$ & $r_{s}$ & $\mathrm{p}$ & $\mathrm{r}_{\mathrm{s}}$ & $\mathrm{p}$ \\
\hline $\begin{array}{l}\text { Contact with patients in } \\
\text { connection with SARS-CoV-2 }\end{array}$ & 0.13 & 0.051 & 0.22 & 0.001 & 0.20 & 0.002 & 0.18 & 0.004 & 0.47 & $<0.001$ \\
\hline $\begin{array}{l}\text { Returning home and studying } \\
\text { at home in connection } \\
\text { with the COVID-19 pandemic }\end{array}$ & 0.28 & $<0.001$ & 0.14 & 0.027 & 0.14 & 0.035 & 0.12 & 0.063 & 0.06 & 0.350 \\
\hline $\begin{array}{l}\text { Lack of contact with colleagues } \\
\text { from the university to } \\
\text { the same degree as prior } \\
\text { to the COVID- } 19 \text { pandemic }\end{array}$ & 0.10 & 0.131 & 0.17 & 0.009 & 0.15 & 0.018 & 0.15 & 0.020 & 0.14 & 0.034 \\
\hline $\begin{array}{l}\text { Lifestyle changes during } \\
\text { the COVID-19 pandemic }\end{array}$ & 0.04 & 0.502 & 0.21 & 0.001 & 0.19 & 0.004 & 0.20 & 0.002 & 0.24 & $<0.001$ \\
\hline $\begin{array}{l}\text { Increased number of study- } \\
\text { related obligations during } \\
\text { the COVID-19 pandemic }\end{array}$ & 0.18 & 0.005 & 0.26 & $<0.001$ & 0.30 & $<0.001$ & 0.38 & $<0.001$ & 0.14 & 0.028 \\
\hline $\begin{array}{l}\text { Increased number of } \\
\text { extracurricular obligations } \\
\text { during the COVID-19 } \\
\text { pandemic }\end{array}$ & 0.20 & 0.002 & 0.22 & 0.001 & 0.27 & $<0.001$ & 0.30 & $<0.001$ & 0.16 & 0.017 \\
\hline $\begin{array}{l}\text { Fear of backlog arising from } \\
\text { the COVID-19 pandemic }\end{array}$ & 0.15 & 0.022 & 0.33 & $<0.001$ & 0.36 & $<0.001$ & 0.44 & $<0.001$ & 0.29 & $<0.001$ \\
\hline $\begin{array}{l}\text { Changes in the form of contact } \\
\text { with assistants during } \\
\text { the COVID-19 pandemic }\end{array}$ & 0.16 & 0.011 & 0.17 & 0.009 & 0.17 & 0.009 & 0.24 & $<0.001$ & 0.16 & 0.015 \\
\hline $\begin{array}{l}\text { Lack of practical classes with } \\
\text { patients in connection with } \\
\text { the COVID-19 pandemic }\end{array}$ & 0.02 & 0.747 & 0.15 & 0.017 & 0.18 & 0.005 & 0.16 & 0.011 & 0.42 & $<0.001$ \\
\hline $\begin{array}{l}\text { Sudden change in the teaching } \\
\text { method to e-learning due } \\
\text { to the COVID-19 pandemic }\end{array}$ & 0.11 & 0.103 & 0.10 & 0.129 & 0.22 & 0.001 & 0.24 & $<0.001$ & 0.16 & 0.013 \\
\hline $\begin{array}{l}\text { Return to clinical classes and } \\
\text { contact with patients in } \\
\text { connection with SARS-CoV-2 }\end{array}$ & 0.07 & 0.316 & 0.29 & $<0.001$ & 0.33 & $<0.001$ & 0.31 & $<0.001$ & 0.50 & $<0.001$ \\
\hline
\end{tabular}

changes in both mental (anxiety, depression, hostility, fear, tension, frustration) and physical (gastrointestinal disorders, diarrhea, constipation, loss of appetite, gluttony, sleep disorders, fatigue, dizziness, tachycardia, dry mouth, sweating hands) spheres [18].
In this research, which was carried out during the period of social isolation, the authors found a variety of sources of stress with various levels of severity in particular years of studies. Compared to the results of the observations carried out prior to the pandemic, as presented by other re- 
searchers, they also observed an increase in the strength of the previously insignificant stressors [18-20,23-25].

Students in their clinical years of studies (i.e., the third, fourth and fifth years) exhibited higher levels of stress as measured by the overall value of DES than students in their first 2 years. The highest value was achieved for the final year; additionally, a significant increase in stress was recorded in the third year. Naidu et al. [21] also found that the levels of stress increased with advanced studies; a particular increase in their intensity was observed at the time of transition from pre-clinical to clinical classes. Contrastingly, Elani et al. [19], in a systematic review, indicated a certain regularity in changes in the intensity of stressors during studies. Longitudinal observations proved that stress related to work overload and clinical factors increased along with the duration of studies, while those associated with faculty and administration factors decreased.

This contradicts the research by Menck Sangiorgio et al. [24] which indicated a decrease in the overall levels of stressors as students progressed with their program. However, it should be remembered that the results presented here refer to the situation at a specific university. The domain of academic work generated the highest level of stress in the present research. This phenomenon was observed in all years of studies, but especially in the final year, where the level of stress was the highest not only for this but for all other domains except living accommodation. Similarly high stress was recorded in the academic work domain for the first year of studies.

The dominant role of academic work in generating stress has also been demonstrated in other studies [18-21,24]. Elani et al. [19] found that this stressor was equally strong at the pre-clinical and clinical stages of studies.

The highest level of stress in this domain during the COVID-19 pandemic was generated by the fear of failing a course or the entire year. It should be noted that in previously published studies the main stressors were examinations and workload, which intensified along with the duration of studies [19]. It is worth emphasizing that in this research the amount of assigned coursework was no longer as strong a stressor as in studies published by other researchers. In the group of students who were surveyed by the authors, this remained at a relatively high level throughout all years of studies, peaking in the fifth year. Based on this research, one might venture to say that during the pandemic, students sensed a threat to the maintenance of the continuity of their education and probably wished to maintain this continuity even at the cost of more intensive work. This is evidenced by the fear of backlog, which was greatly stressed by students of all years of studies.

A very high level of stress, although significantly lower than in the previously described domain, was generated by clinical factors. These values were high for the years of studies in which clinical teaching is implemented. Significantly, the lowest level of stress in this domain was recorded for first-year students. Hence, it can be concluded that students starting their studies are not subject to the pressure of difficulties in clinical classes, as their commencement is a fairly distant prospect. The transition from pre-clinical to clinical activities, similar to the remaining items in this domain, does not cause them undue stress. However, in the second year, the awareness of all potential problems associated with this transition is sensed more and more acutely, as students approach their first contacts with patients and the need to perform treatment themselves. Therefore, the level of stress associated with clinical activities in the third year of studies is high - significantly higher than in the second year, and only slightly lower than the highest value in this domain, which is in the fifth year. A similar aggravation of stress related to the transition from pre-clinical to clinical activities was described by Hayes et al. [23].

In the years of the clinical study during the COVID-19 pandemic, the most stressful aspects were: the shortage of allocated clinical time, especially in the third year; stress 
resulting from completing clinical requirements; a lack of confidence in relation to the student's own clinical decision-making; and differences in opinions with clinical staff concerning treatment. Slightly lower levels of stress were associated with patient management, and the degrees of manual skills and the ability to perfect them.

Similar observations were described by Elani et al. [19]. In their systematic review, clinical factors were rated second, after academic work, in the ranking of DES domains. Additionally, longitudinal studies showed increasing values of stress for clinical factors along with an increased duration of studies.

Educational environment generated significantly less stress in the group of the surveyed students than did the domains described above, similarly as was presented in the publications of other researchers [19,20,23,24]. Only Garbee et al. [18], in their research conducted in the 1980s, presented the academic environment and clinical environment created by the faculty as the highest-level stressor, including especially the atmosphere created by clinical professors.

As in the previous domains, fifth-year students again exhibited the highest level of stress. The most stressful aspect during the COVID-19 pandemic was expectations vs. reality of attending a dental school, chiefly in the third and fifth years. It can be assumed that the COVID-19 pandemic, the state of social isolation, the forced change in the manner of teaching, and uncertainty related to the future were not without significance in this situation. Critical remarks by those conducting lessons as well as university rules and regulations were also strong stressors, similarly as in the systematic review by Elani et al. [19], where the highest stress values were assigned to regulations and rules in schools, receiving criticism, and inconsistency of feedback from staff.

In discussing the most stressful domains, it is worth noting that Murphy et al. [26] showed that dental students displayed significantly higher levels of stress in these domains than medical students, and that the values for academic work were the highest in both fields of studies.

As in other studies, the lowest level of stress was noted in the domains of personal factors and living accommodation $[19,20,23,24]$. In the latter area, the greatest stressor was the lack of time for rest/relaxation, especially in the fourth and fifth years of studies. There were also problems related to the postponement of starting a family/ having children, which became more and more stressful over time. In the last year of studies, tensions related to conflicts with a loved one over continued professional development were also noted. Most likely, this stress resulted from internal conflicts generated by the awareness of the simultaneous needs for continued professional development and family responsibilities, which constituted a major challenge.

The authors conducted their research in a unique situation: a pandemic caused by a new pathogen, the study of which had just begun. Social isolation and restrictions in all areas of life also influenced the functioning of the university. The entire academic community found itself in a new reality. It became necessary to develop new rules of operation that would enable education to continue.

In this new situation, the authors made an attempt to identify the sources of dental environmental stress during the pandemic. Additionally, they examined the relationship between the situation resulting from the pandemic and the stress described in the DES questionnaire. They found the strongest positive correlation between clinical factors, and the prospect of a return to clinical classes and the related contact with patients with regard to SARSCoV-2, followed by contact with such patients in general. Also deserving attention in this domain is a relatively strong positive correlation with the lack of practical classes with patients in connection with the COVID-19 pandemic. In the domain of academic work, the strongest positive correlation was found with the fear of backlog arising from the COVID-19 pandemic. 
These results demonstrate the awareness resulting from the dangers connected with the pandemic, which represents, on the one hand, the threat of a new infectious disease and, on the other, a disruption in the course of studies and uncertainty about the future. Based on research by Huang and Zhao [13], it can be assumed that, in this situation, dentistry students constitute a group particularly burdened by the effects of this stress. These researchers showed that healthcare workers - particularly young ones - involved in combating the COVID-19 pandemic that is, working in contact with, or exposed to potential contact with, a SARS-CoV-2 patient - suffer from disorders in normal mental functionality [13].

Publications related to the adaptation of education of dental students to the conditions of the pandemic emphasize the necessity not only of changing the curriculum (expanding the knowledge of infectious diseases and methods of preventing their spread) but also of providing psychological support for the entire academic community $[6-10,13,15-17]$.

It should be emphasized that there is a need to monitor stressors among dentistry students as the pandemic continues, and to obtain longitudinal results. There is also a need for future research aimed at exploring and testing stress management interventions in individual student environments, as each university has its own specific characteristics.

\section{CONCLUSIONS}

During the COVID-19 pandemic, among dentistry students at the Jagiellonian University, the gradation of stress in DES domains, as described by previous researchers, was demonstrated. Within individual domains, shifts occurred in the levels of stress assigned to individual stressors.

Due to the appearance of the fear of backlog arising from the pandemic and failure to pass the required program, the authors venture to say that students were ready to make greater efforts to carry out the study program. Dental students were subjected to stress resulting from conflicts between the perceived risk of returning to clinical classes and contact with patients due to SARS-CoV-2, and disruptions in the course of clinical education, which they perceived negatively.

\section{ACKNOWLEDGMENTS}

The authors would like to thank all the participating students.

\section{REFERENCES}

1. World Health Organization [Internet]. Geneva: The Organization; 2015 [cited 2020 Apr 11]. WHO publishes list of top emerging diseases likely to cause major epidemics. Available from: https://www.who.int/medicines/ebola-treatment/WHOlist-of-top-emerging-diseases/en/.

2. World Health Organization [Internet]. Geneva: The Organization; 2018 [cited 2018 Feb 6]. 2018 Annual review of diseases prioritized under the Research and Development Blueprint. Available from: https://www.who.int/emergencies/ diseases/2018prioritization-report.pdf.

3. Sweileh WM. Global research trends of World Health Organization's top eight emerging pathogens. Global Health. 2017;13(1):9.

4. Al-Hazari A. Challenges presented by MERS corona virus, and SARS corona virus to global health. Saudi J Biol Sci. 2016;23(4):507-11.

5. Fallahi HR, Keyhan SO, Zandian D, Kim SG, Cheshmi B. Being a front-linedentist duringthe COVID-19 pandemic: a literature review. Maxillofac Plast Reconstr Surg. 2020;42(1):12, https://doi.org/10.1186/s40902-020-00256-5.

6. Ghai S. Are dental schools adequately preparing dental students to face outbreaks of infectious diseases such as COVID-19? J Dent Educ. 2020;84(6):631-3.

7. Deery C. The COVID-19 pandemic: implications for dental education. Evid Based Dent. 2020;21(2):46-7.

8. Iyer P, Aziz K, Ojcius DM. Impact of COVID-19 on dental education in the United States. J Dent Educ. 2020;84(6):718-22. 
9. Tomsah MH, Al-Sohi F, Alamro N, Al-Eyadhy A, Al-Hasan K, Jamal A, et al. The psychological impact of COVID-19 pandemic on health care workers in MERS-CoV endemic country. J Infect Public Health. 2020;13(6):877-82.

10. World Health Organization [Internet]. Geneva: The Organization; 2020 [cited 2020 Mar 11]. WHO Director-General's opening remarks at the media briefing on COVID-19 11 March 2020. Available from: https://www.who.int/dg/spee ches/detail/who-director-general-s-opening-remarks-at-themedia-briefing-on-COVID-19---11-march-2020.

11. Velavan TP, Meyer CG. The COVID-19 epidemic. Trop Med Int Health. 2020;25(3):278-80.

12. Tang A, Tong Z, Wang H, Dai X, Li K, Liu J, et al. Detection of Novel Coronaviruses by RT-PCR in Stool Specimen from Asymptomatoc Child, China. Emerg Infect Dis. 2020;26(6):1337-9.

13. Huang Y, Zhao N. Mental health burden for the public affected by the COVID-19 outbrake in Cina: Who will be the high-risk grop? Psychol Health Med. 2020:1-12, https:// doi.org/10.1080/13548506.2020.1754438.

14. Sierpiński R, Pinkas J, Jankowski M, Juszczyk G, Topór-Madry R, Szumowski Ł. Occupational risks for SARS-CoV-2 infection: The Polish experience. Int J Occup Med Environ Health. 2020;33(6):781-9, https://doi.org/10.13075/ijomeh.1896.01663.

15. Asaoko H, Koido Y, Kawashima Y, Ikeda M, Miyamoto Y, Nishi D. Post-traumatic stress symptoms among medical rescue workers exposed to COVID-19 in Japan. Psychiatry Clin Neurosci. 2020;74(9):503-5, https://doi.org/10.1111/pcn.13092.

16. Kounou KB, Guédénon KM, Dogbe Foli AA, GnassounouAkpa E. Mental health of medical professionals during the COVID-19 pandemic in Togo. Psychiatry Clin Neurosci. 2020; 74(10):559-60, https://doi.org/10.1111/pcn.13108.

17. Vindegaard NV, Benros ME. COVID-19 pandemic and mental health consequences: Systematic review of the current evidence. Brain Behav Immun. 2020;S0889-1591(20)30954-5, https://doi.org/10.1016/j.bbi.2020.05.048.

18. Garbee WH, Zucker SB, Selby GR. Perceived sources of stress among dental students. J Am Dent Assoc. 1980;100(6): 853-7, https://doi.org/10.14219/jada.archive.1980.0279.

19. Elani HW, Allison PJ, Kumar RA, Mancini L, Lambrou A, Bedos C. A systemic review of stress in dental students. J Dent Educ. 2014;78(2):226-39.

20. Harris M, Wilson JC, Holmes S, Radford DR. Perceived stress and well-being among dental hygiene and dental therapy students. Br Dent J. 2017;222(2):101-6, https://doi.org/ 10.1038/sj.bdj.2017.76.

21. Naidu RS, Adams JS, Simeon D, Persasd S. Sources of Stress and Psychological Disturbances Among Dental Students in the West Indies. J Dent Educ. 2002;66(9):1021-30.

22. Lazarus RS, Folkman S. Stress, appraisal, and coping. New York: Springer Publishing Company; 1984.

23. Hayes A, Hoover JN, Karunanayake CP, Uswak GS. Perceived causes of sress among a group of western Canadian dental students. BMC Res Notes. 2017;10(1):714-23, https:// doi.org/10.1186/s13104-017-2979-9.

24. Menck Sangiorgio JP, Medeiros Araujo P, Hirata Navarro C, Renan Zen I, da Costa SC, Vivan Ribeiro PH, et al. Dental Environment Stress: Findings among Lusophone Dental Students [Internet]. Braz Res Pediatr Dent Integrated Clin. 2016;16(1):411-24 [cited 2020 Apr 11], https://www.redalyc. org/articulo.oa? $\mathrm{id}=63749588043$.

25. Sanders AE, Lushington K. Effect of perceived stress on student performance in dental school. J Dent Educ. 2002; $66(1): 75-80$.

26. Murphy RJ, Gray SA, Sterling G, Reeves K, DuCette J. A comparative study of professional student stress. J Dent Educ. 2009;73(3): 328-37.

This work is available in Open Access model and licensed under a Creative Commons Attribution-NonCommercial 3.0 Poland License - http://creativecommons.org/ licenses/by-nc/3.0/pl/deed.en. 